\title{
Timing of Cholecystectomy in Mild Acute Biliary Pancreatitis.
}

\author{
Orhan Alimoğlu1, Nuray Colapkulu1 ${ }^{1}$, Tunç Eren ${ }^{1}$
}

\begin{abstract}
Background: Acute biliary pancreatitis $(\mathrm{ABP})$ is one of the most common gastrointestinal events that requires acute admission to the hospital with considerable risks of mortality \& morbidity. Laparoscopic cholecystectomy has become the gold standard for the treatment of ABP. Our aim was to determine the safety of cholecystectomy during the first admission by performing a review of the current literature. Waiting for 6 - 8 weeks to perform cholecystectomy may result with an increased incidence of recurrent ABP attacks, which may increase morbidity and the length of the hospital stay. On the contrary, cholecystectomy during the index admission for mild ABP appears to be a preferable and safe approach with better surgical outcomes providing a definitive treatment.
\end{abstract}

Keywords: Pancreatitis, cholecystectomy, general surgery

*Correpsonding Author: Orhan Alimoğlu

$\equiv \triangle$ Email: orhanalimoglu@gmail.com

1Department of General Surgery, Fakulty of Medicine, Istanbul Medeniyet University, Istanbul, Turkey 


\section{Full Text}

\section{Gallstone disease and its complications}

Gallstone disease is considered as an important health problem worlwide, affects quality of life and causes severe morbidity and even mortality. Gobally, the incidence of gall stone disease is approximately $10-15 \%$ [1]. The prevelance of this entity is dependent on variable risk factors, which could be identified as modifiable and nonmodifiable (Table 1) [1]. The incidence increases over the years, especially due to non-modifiable risk factors and there is a concordant increase in complication rates such as acute biliary pancreatitis (ABP) [2]. ABP is a common gastrointestinal inflammatory condition and most patients develop a mild course; however, some patients may have severe inflammatory response and mortality is usually associated with multiorgan dysfunction in this group [3].

\begin{tabular}{l|l} 
Non-modifiable & \multicolumn{1}{c}{ Modifiable } \\
\hline Family history & $\begin{array}{l}\text { Obesity / metabolic syndrome / diabetes mellitus / } \\
\text { dyslipidemia }\end{array}$ \\
\hline Genetic factors & $\begin{array}{l}\text { Drugs - ceftriaxone, thiazide diuretics, octreotide, female } \\
\text { sex hormones }\end{array}$ \\
\hline Ethnicity & Decreased physical activity \\
\hline Female gender & Rapid weight loss \\
\hline Age & Total parenteral nutrition \\
\hline & Dietary factors \\
\hline & Underlying disease - cirrhosis
\end{tabular}

Table 1. Risk factors for gallstone disease [1].

\section{Acute biliary pancreatitis}

The definition of acute pancreatitis is that it is an inflammatory condition of the pancreas with a wide spectrum of pathophysiological aspects that shows different types of severeness; such as edema or necrosis that is associated with poor or no fibrosis [4]. Concomitant stones in the biliary ducts are present in $6-12 \%$ of people with gallstones, and based on the 
differences in site of formation and pathogenesis, common bile duct (CBD) stones can be classified as primary and secondary biliary stones $[5,6]$. If a stone forms in the CBD, it's called a primary stone, whereas migrated stones from the gallbladder that locate in the CBD are called secondary stones [7]. Migration of gallstones especially smaller than $3 \mathrm{~mm}$ through the cystic duct to the CBD is thought to be the pathophysiology behind ABP. In 1901, Opie observed impacted stones at the site of the sphincter of Oddi in two mortal cases. Temporary obstruction of the ampulla of Vater by stones causes bile reflux towards the pancreas via the common channel and regurgitation continues through the pancreatic duct. Normally, inactive digestive zimogens and lyzsozyme hydrolase stay apart in pancreatic cells. If ductal obstruction occurs, they colonize together in vacuoles in the cells and uncontrolled activation of trypsin leads to autodigestion of the pancreas and local inflammation $[8,9]$. Biliary stones are considered to be responsible for $\mathrm{ABP}$ in $30-70 \%$ of cases. In addition to the aformentioned risk factors, male gender is associated with increased possibility of complicated forms leading to morbidity and mortality [10].

\section{Severity assessment in acute biliary pancreatitis}

Scoring systems based on clinical, laboratory and radiological findings to predict the prognosis of pancreatitis have been identified and used in medical practice for decades. The most frequently used are the Balthazar and Ranson's scoring systems as well as the Atlanta Classification.

In 1992, the Atlanta Classification was created for a standardized clinical approach and revised in 2012 [11,12]. According to the Revised Atlanta Classification, the clinical presentation must meet the criteria as follows: acute onset of severe, persistent, epigastric pain often radiating to the back. The pain relieves by leaning forward and is aggravated by food in most cases. According to the laboratory findings, the serum lipase level is at least three times increased. Radiologic work-up is unnecessary to be carried out immediately if the first two criteria are present [11]. The Revised Atlanta classification of acute pancreatitis identified three grades of severity, which were the "mild form" (no organ dysfunction, or local/systemic complications), the "moderate form" (organ failure that ameliorates within 48 hours and/or local or systemic complications), and the "severe form" (persistent organ failure lasting for $>48$ hours, single or multiple) [11]. There also had been changes in radiological severity in the Revised Atlanta Classification [12] (Table 2). 
Another approach to foresee the prognosis of ABP is the Ranson's score which was first described in 1974 by Ranson et al, and then modified in 1979 based on the etiology for biliary disease [13,14] (Table 3).

Balthazar et al published two studies in 1985 and 1990 about the prognostic value of computerized tomography (CT) in acute pancreatits $[15,16]$. Patients without peripancreatic inflammation were found to be associated with the uncomplicated (mild) form, whereas patients with one or several peripancreatic collections were associated with the severe form, and were more likely to develop serious complications [16] (Table 4).

\begin{tabular}{|c|c|c|}
\hline & $\begin{array}{l}\text { Original Atlanta } \\
\text { Classification }\end{array}$ & Revised Atlanta Classification \\
\hline Acute & Interstitial pancreatitis & Interstitial edematous pancreatitis \\
\hline pancreatitis & Steril necrosis & $\begin{array}{l}\text { Necrotizing pancreatitis } \\
\text { (pancreatic and/or peripancreatic } \\
\text { necrosis) }\end{array}$ \\
\hline & Infected necrosis & $\begin{array}{l}\text { Sterile necrosis } \\
\text { Infected necrosis }\end{array}$ \\
\hline $\begin{array}{l}\text { Fluid } \\
\text { collections } \\
\text { during } \\
\text { acute } \\
\text { pancreatitis }\end{array}$ & $\begin{array}{l}\text { Pancreatic pseudocyst } \\
\text { Pancreatic abscess }\end{array}$ & $\begin{array}{l}<4 \text { weeks after onset of acute } \\
\text { pancreatitis } \\
\quad-\quad \text { Acute peripancreatic fluid } \\
\quad \text { collection } \\
\text { Sterile necrosis } \\
\text { Infected necrosis } \\
\quad-\quad \text { Acute necrotic collection } \\
\text { Sterile necrosis } \\
\text { Infected necrosis } \\
\text { <4 weeks after onset of acute } \\
\text { pancreatitis } \\
\quad \text { - Pancreatic pseudocyst } \\
\text { Sterile necrosis } \\
\text { Infected necrosis } \\
\quad \text { - Walled-off pancreatic } \\
\text { necrosis } \\
\text { Sterile necrosis } \\
\text { Infected necrosis }\end{array}$ \\
\hline
\end{tabular}


Table 2. Comparison of the Original and Revised Atlanta Classification systems [12].

\begin{tabular}{|l|c|}
\hline \multicolumn{1}{|c|}{ Parameter } & $\begin{array}{c}\text { Gallstone-induced } \\
\text { pancreatitis }\end{array}$ \\
\hline On admission & $>70$ \\
Age & $>18000$ \\
WBC & $>220$ \\
Glucose (mg/dL) & $>400$ \\
LDH (IU/L) & $>250$ \\
AST (IU/L) & \\
Within $48 h$ & \\
Hct decrease $(\%)$ & 5 \\
BUN increase (mg/dL) & $>2$ \\
Calcium $(\mathrm{mg} / \mathrm{dL})$ & $<8$ \\
PaO $(\mathrm{mmHg})$ & 52 \\
Base deficit $(\mathrm{mEq} / \mathrm{L})$ & $>5$ \\
Fluid $(\mathrm{L})$ & $>4$ \\
\hline
\end{tabular}

Table 3. Ranson's criteria [17].

Inflammatory process - Balthazar's morphological index for acute pancreatitis

\begin{tabular}{c|l|c}
\hline Grade & \multicolumn{1}{|c|}{ Tomographic finding } & Scoring \\
\hline A & Normal pancreas. & 0 \\
\hline B & Focal or diffuse pancreatic enlargement. & 1 \\
\hline $\mathbf{C}$ & Pancreatic alternations associated with peripancreatic inflammation. & 2 \\
\hline D & Single fluid collection. & 3 \\
\hline E & $\begin{array}{l}\text { Two or more fluid collections and/or presence of gas within the } \\
\text { pancreas or within peripancreatic inflamation. }\end{array}$ & 4 \\
\hline
\end{tabular}

Pancreatic necrosis

\begin{tabular}{|l|c|}
\hline Tomographic finding & Scoring \\
\hline Absence of necrosis. & 0 \\
\hline$<30 \%$ necrosis. & 2 \\
\hline
\end{tabular}


30-50\% necrosis.

$>50 \%$ necrosis.

4

6

Table 4. Balthazar's scoring system [18].

\section{Cholecystectomy for acute}

\section{biliary pancreatitis}

The definitive treatment of mild ABP is cholecystectomy after resolution of the symptoms and clinical improvement. Several approaches are applied based on the optimal timing for cholecystectomy. Early cholesystectomy during the the first admission, after the resolution of clinical and laboratory parameters, is suggested by current guidelines $[19,20]$. In their prospective study, published in 1981, Stone et al compared early and delayed open cholecystectomy after biliary pancreatitis, and given the surgical outcomes, complication rates, and hospital stay, they concluded that early and delayed surgery were equally safe [21].

Although there is no consensus on the timing for delayed cholecystectomy, performing surgery up to 8 weeks after the pancreatitis attack can be defined as interval surgery. Cholecystectomy during the first admission is recommended by the International Association of Pancreatology, while the American Gastroenterological Association suggests delayed cholecystectomy after 2-4 weeks following discharge [22,23]. The British Society of
Gastroenterology

recommends cholecystectomy at first admission or up to 2 weeks after admission [24].

\section{Recurrence and readmission}

In his study of 80 patients with pancreatitis, published in 1979, Ranson operated on 59 patients and suggested that although early surgical treatment for the associated biliary condition could be carried out safely in many patients with "mild" acute pancreatitis, early definitive surgery was insecure in "severe" pancreatitis and should, if possible, be delayed until pancreatitis subsided and that most patients should be operated before hospital discharge [14]. In a meta-analysis by Baal et al, increased rates of readmissions after $A B P$ attacks were reported to be associated with the interval time periods between the first admissions and the delayed surgical interventions of the patients [25]. The risk of developing a recurrent biliary attack was reported as 9-60\% following discharge before delayed surgery [26]. Ito et al suggested that a two-weeksinterval between the first attack and surgical intervention might be too long 
because $31 \%$ of recurrences occured within two weeks after the first admission [27]. According to three prospective randomized controlled studies and 10 retrospective studies evaluating the surgical outcomes, complications, hospital stay, and readmission rates analyzed in a review, when compared between early and delayed cholecystectomy operations, the rates of conversion to open surgery were similar, and early cholecystectomy was associated with decreased incidence of recurrent $\mathrm{ABP}$ attacks, morbidity and hospital stay [20].

\section{Complications}

A meta-analysis showed no variation in complication rates between early and delayed surgery [28]. In another meta-analysis it was found that delayed laparoscopic cholecystectomy resulted in higher rates of complications and readmission than early laparoscopic cholecystectomy while the rates of conversion to open cholecystectomy between early laparoscopic cholecystectomy and delayed laparoscopic cholecystectomy were comparable [20].

One of the indicators for difficult surgery is operative time. When the studies were analyzed in our review, it was found that the timing of cholecystectomy did not affect the duration of surgery. Early surgery decreases the risk of recurrent biliary complications. In our opinion, cholecystectomy in patients with mild to moderatley severe biliary pancreatitis can be performed safely during the first admission.

\section{Conversion to open surgery}

Although most guidelines suggest early cholecystectomy because of the high rates of reccurent $\mathrm{ABP}$ attacks that are clearly associated with more complicated disease and other gallstone related events, the answer is still unclear for the question: "Why do most surgeons delay surgery?". It can be thought that delayed surgery can be associated with relatively easier surgery due to regressed inflamation and possibly lower convertion rates [29]. Early cholecystectomy, on the other hand, is believed to be harder to perform due to increased inflamation. The conversion rates to open surgery between early and delayed cholecystectomy were approximately $7.5 \%$ and $7 \%$, respectively, according to several studies [30,31]. Even though there is an assumption that early cholecystectomy is harder to perform, no difference was shown in concern of operative time or surgical complications between studies accoeding to the available data [20]. 


\section{Length of hospital stay}

Delayed surgery was associated with a significantly longer length of hospital stay and those patients require readmission and a longer duration of conservative treatment. In their study of 72 patients, Jee et al reported that the patients who underwent delayed surgery had longer hospital stay than the patients who underwent early surgery during the first admission since $24 \%$ of these cases readmitted due to recurrent gall-stone related events most of which could have been preventable with early cholecystectomy [26]. In summary, delayed surgery results with longer hospital stay, increases hospitalization costs and leads to excessive consumption of medical resources.

\section{Conclusions}

The timing of cholecystectomy in ABP should be decided according to the severity of the disease and the clinical course of the individual patient. Definitive treatment of mild ABP can be accomplished effectively and safely via cholecystectomy following clinical improvement and normalized levels of laboratory parameters during the first admission. Delayed cholecystectomy following a 6 to 8 weeks' time period may result with recurrent gallstone pancreatitis, which may increase morbidity rates and the duration of hospital stay.

\section{References}

1. Shaffer

EA

(2005)

Epidemiology and risk factors for gallstone disease: has the paradigm changed in the 21st century? Curr Gastroenterol $\operatorname{Rep~7(2):132-140.~}$

2. Lindkvist B, Appelros S, Manjer J, Borgström A (2004) Trends in incidence of acute pancreatitis in a Swedish population: is there really an increase? Clin Gastroenterol Hepatol 2(9):831837.

3. Peery AF, Dellon ES, Lund J, Crockett SD, McGowan CE, Bulsiewicz WJ, Gangarosa LM, Thiny MT, Stizenberg K, Morgan DR, Ringel Y, Kim HP, DiBonaventura MD, Carroll CF, Allen JK, Cook SF, Sandler RS, Kappelman MD, Shaheen NJ (2012) Burden of gastrointestinal disease in the United States: 2012 update. Gastroenterology 143(5):11791187.

4. Petrov MS, Shanbhag S, Chakraborty M, Phillips AR, Windsor JA (2010) Organ failure and infection of pancreatic necrosis as deteminants of mortality in patient with acute 
pancreatitis. Gastroenterology 139(3):813-820.

5. Ko CW, Lee SP (2002) Epidemiology and natural histroy ofcommon bile duct stones and prediction of disease. Gastrointest Endosc 56(6):S165169.

6. Liu TH, Moody FG (2000) Pathogenesis and presentation of common bile duct stones. Semin Laparosc Surg 7(4):224231.

7. Saharia PC, Suidema GD, Cameron JL (1997) Primary common bile duct stones. Ann Surg 185: 598-604.

8. Lee SP, Nicholls JF, Park HZ (1992) Biliary sludge as a cause of acute pancreatitis. N Engl J Med 326(9):589-593.

9. Acosta JM, Ledesma CL (1974) Gallstone migration as a cause of acute pancreatitis. N Engl J Med 290(9):484-487.

10. Shen HN, Wang WC, Lu CL, Li CY (2013) Effects of gender on severity, management and outcome in acute biliary pancreatitis. PLoS One 8(2):e57504.

11. Banks PA, Bollen TL, Dervenis C, Gooszen HG, Johnson CD, Sarr MG, Tsiotos GG, Vege SS. Acute Pancreatitis Classification Working Group (2013) Classification of acute pancreatitis - 2012: revision of the Atlanta classification and definitions by international consensus. Gut 62(1):102-111.

12. Kaawakami $\mathrm{H}$, Itoi $\mathrm{T}$, Sakamato N (2014) Endoscopic ultrasound-guided transluminal drainage for peripancreatic fluid collections: Where are we now? Gut Liver 8(4):341-355.

13. Ranson JHC, Rifkind KM, Roses DF, Fink SD, Eng K, Spencer FC (1974) Prognostic signs and the role of operative management in acute pancreatitis. Surg Gynecol Obstet 139(1):69-81.

14. Ranson JHC (1979) The timing of biliary surgery in acute pancreatitis. Ann Surg 189(5):654-662.

15. Balthazar EJ, Ranson JH, Naidich DP, Megibow AJ, Caccavale R, Cooper MM (1985) Acute pancreatitis: prognostic value of CT. Radiology 156(3): 767-772.

16. Balthazar EJ, Robinson DL, Megibow AJ, Ranson JH (1990) Acute pancreatitis: value of CT in establishing prognosis. Radiology 174(2):331-336.

17. ImrieCW (2003) Prognostic indicators in acute pancreatitis. Can J Gastroenterol 17(5):325328.

18. Freire Filho EDO, Shigueoka DC, Bekhor D, Vieira RLR, Yamada AF, Freire MFDO, Ajzen S, D'Ippolito G (2007) Reproducibility in the assessment of acute pancreatitis 
with computed tomography. Radiol Bras 40(6):383-387.

19. Alimoglu O, Ozkan OV, Sahin M, Akcakaya A, Eryılmaz R, Bas G (2003) Timing of cholecystectomy for acute biliary pancreatitis: Outcomes of cholecystectomy on first admission and after recurrent biliary pancreatitis. World J Surg 27(3):256-259.

20. Yang DJ, Lu HM, Guo Q, Lu S, Zhang L, Hu WM (2018) Timing of laparoscopic cholecystectomy after mild biliary pancreatitis: a systematic review and metaanalysis. J Laparoendosc Adv Surg Tech A 28(4):379-388.

21. Stone H, Fabian TC, Dunlop WE (1981) Gallstone pancreatitis: Biliary tract pathology in relation to time of operation. Ann Surg 194(3):305-312.

22. Besselink $M$, van Santvoort $H$, Freeman M, Gardner T, Mayerle J, Vege SS, Werner J, Banks P, McKay C, Fernandez-del Castillo C, French J, Gooszen H, Johnson C, Sarr M, Takada T, Windsor J, Saluja A, Liddle R, Papachristou G, Singh V, Rünzi M, Mayerle J, Wu B, Singh V, Windsor J, Banks $P$, Papachristou G, Bollen T, Morgan D, Mortele K, Mittal A, Windsor J, En-qiang M, Gardner $\mathrm{T}$, Mayerle J, Mayerle J, Johnson C, de Waele J, van Santvoort H, Petrov M, Dellinger P, Besselink
M, Lerch MM, Gardner T, Petrov M, Anderson R, McClave S, Gardner T, Hartwig W, van Santvoort H, Freeman M, Bruno M, Oria A, Banks P, Mayerle J, Besselink M, Gardner T, Gooszen H, Baron T, Castillo CF, Werner J, Fagenholz P, Besselink M, van Santvoort $H$, Baron T, Horvath K, Bollen T, Mortele K, Werner J, Freeman $M$, van Baal $M$, Nealon $W$, Gardner T, Mayerle J, AndrenSandberg A, Bakker O, Bassi C, Buchler $M$, Boermeester $M$, Bradley E, Chari S, Charnley R, Connor S, Dervenis C, Deviere J, Dudeja V, Fockens P, Forsmark C, Friess H, Isaji S, Isenmann R, Klar E, Lévy P, Lillemoe K, Liu $X$, Löhr CM, Mayumi T, Mossner J, Neoptolemos J, Nordback I, Olah A, Padbury R, Parks R, Radenkovic D, Rau B, Rebours V, Seewald S, Seifert H, Shimosegawa T, Siriwardena A, Steinberg W, Sutton R, Tanaka M, Takeda K, Tse F, van Goor $\mathrm{H}$, Warshaw A, Wang C, Whitcomb D, Zhao Y, Zyromski N. Working Group IAP/APA Acute Pancreatitis Guidelines (2013) IAP/APA evidencebased guidelines for the management of acute pancreatitis. Pancreatology 13(4 Suppl 2):e1-15.

23. Baillie J (2007) AGA Institute medical position statement on 
acute

pancreatitis.

Gastroenterology 132(5):20192021.

24. Working Party of the British Society of Gastroenterology, Association of Surgeons of Great Britain and Ireland, Pancreatic Society of Great Britain and Ireland (2005) UK guidelines for the management of acute pancreatitis. Gut 54(Suppl 3):iii1-iii9.

25. van Baal MC, Besselink MG, Bakker OJ, van Santvoort HC, Schaapherder AF, Nieuwenhuijs VB, Gooszen HG, van Ramshorst B, Boerma D, Dutch Pancreatitis Study Group (2012) Timing of cholecystectomy after mild biliary pancreatitis: A systematic review. Ann Surg 255(5):860-866.

26. Jee SL, Jarmin R, Lim KF, Raman K (2018) Outcomes of early versus delayed cholecystectomy in patients with mild to moderate acute biliary pancreatitis: A randomized prospective study. Asian J Surg 41(1):47-54.

27. Ito K, Ito $\mathrm{H}$, Whang EE (2008) Timing of cholecystectomy for biliary pancreatitis: Do the data support current guidelines? J Gastrointest Surg 12(12):21642170.

28. Randial Perez LJ, Fernando PJ, Aldana DG (2014) The safety of early

laparoscopic cholecystectomy ( $<48$ hours) for patients with mild gallstone pancreatitis: A systematic review of the literature and meta-analysis. Cir Esp 92(2):107-113.

29. Tate JJ, Lau WY, Li AK (1994) Laparoscopic cholecystectomy for biliary pancreatitis Br J Surg 81(5):720-722.

30. Genc V, Sulaimanov M, Cipe G, Basceken SI, Erverdi N, Gurel M, Aras N, Hazinedaroglu SM (2011) What necessitates the conversion to open cholecystectomy? A retrospective analysis of 5164 consecutive laparoscopic operations.Clinics (Sao Paulo) 66(3):417-420.

31. Sinha R (2008) Early laparoscopic cholecystectomy in acute biliary pancreatitis: The optimal choice? HPB (Oxford) 10(5):332-335. 